Carolina Barbosa MALEK DOS REIS ${ }^{1}$

Roberto Coloza

HOFFMANN ${ }^{2}$

Regina da Silva SANTOS ${ }^{1}$

Rosimary de Jesus Gomes TURRI

Maria Raquel de Godoy ORIANI ${ }^{1}$

Correspondência para:

Av. Doutor Octávio Bastos s/n, Jardim Nova São João, 13874159-São João da Boa Vista/ SP-carolmalek@uol.com.br

Recebido para publicação: 30/08/2006 Aprovado para publicação: 23/08/2007

\title{
Pesquisa de anticorpos anti-Brucella canis e anti- Brucella abortus em cães errantes da cidade de São João da Boa Vista, Estado de São Paulo, Brasil (2002-2003)
}

1 - Faculdade de Medicina Veterinária do Centro Universitário da Fundação

de Ensino Octávio Bastos, São João da Boa Vista - SP

2 - Centro de Controle de Zoonoses, São João da Boa Vista - SP

\section{Resumo}

A brucelose canina é uma importante zoonose que tem sido investigada freqüentemente em cães como medida sanitária de controle da saúde pública. Foi conduzido um estudo sorológico para investigar a freqüência da brucelose canina por Brucella canis e por Brucella abortus, em 500 cães errantes na cidade de São João da Boa Vista/SP - Brasil, utilizando as técnicas de imunodifusão em gel de ágar (antígeno de parede celular de $B$. ovis) e imunoaglutinação em placa com antígeno acidificado tamponado. Este estudo mostrou baixa frequência de cães infectados por B. canis $4 / 500(0,8 \%)$ e ausência de soros positivos para B. abortus.

A brucelose canina é causada especificamente pela Brucella canis e eventualmente por Brucella abortus, Brucella suis e Brucella melitensis. ${ }^{1}$ A fonte principal de infecção por B. canis são os machos e as cadelas doentes pelo contágio sexual ou pela via oral ${ }^{2}$ enquanto por $B$. abortus é a ingestão de restos placentários de ruminantes brucélicos ${ }^{3,4}$. A doença é transmissível ao homem, sendo uma importante zoonose, principalmente de caráter ocupacional ${ }^{5}$, embora cães errantes possam ser uma importante fonte de infecção.

Considerando-se a ausência de dados epidemiológicos regionais e o caráter zoonótico dessa infecção, o objetivo desse trabalho foi determinar a freqüência de anticorpos anti-Brucella canis e anti-Brucella abortus, em cães errantes da cidade de São João da Boa Vista/SP, no período de 2003 a 2004. Foram utilizados soros de 500 cães de variadas raças, de ambos os sexos e diferentes idades, procedentes do Centro de Controle de Zoonoses (CCZ) da cidade de São João da Boa Vista/SP. As amostras de sangue foram colhidas assepticamente da veia safena ou radial no volume de $5 \mathrm{~mL} /$ animal. Após a retenção do coágulo, o soro sanguíneo foi centrifugado a $1000 \mathrm{rpm}$ durante 10 minutos e então armazenados a temperatura $-20^{\circ} \mathrm{C}$ até a realização das provas sorológicas. Para a pesquisa de anticorpos anti-Brucella canis foi utilizada a técnica de imunodifusão em gel de ágar (IDGA) ${ }^{2}$ com antígenos extraídos da parede celular de Brucella ovis, proteínas e lipopolissacarídeos (Tecpar - Paraná; Instituto de Tecnologia do Paraná) seguindo metodologia descrita pelo fornecedor do antígeno (Tecpar). Para o diagnóstico da infecção por Brucella abortus foi utilizada a técnica de imunoaglutinação em placa com antígeno acidificado tamponado (AAT) com rosa Bengala, empregando antígeno preparado com Brucella abortus amostra 119/ 3 como recomendado por Alton et al. ${ }^{7}$.

Das 500 amostras testadas, quatro soros foram positivos para B. canis e todos se apresentaram negativos para B.abortus. Consideraram-se positivos para B. canis os soros que apresentaram linha de precipitação entre o soro-teste e o poço de antígeno com a continuidade da linha de precipitação do soro-controle positivo; e, para B. abortus 
quando ocorreu aglutinação na reação do soro com o antígeno acidificado tamponado. A frequência de brucelose canina na população de cães errantes, da cidade de São João da Boa Vista, mostrou-se extremamente baixa 4/500 (0,8\%) para Brucella canis e negativa para Brucella abortus. O manejo tipo solto é um evento epidemiológico relevante para a ocorrência da brucelose, pois estes cães possuem contato livre entre os animais aumentando as chances de transmissão da infecção, disseminando a brucelose para a população canina, incluindo os animais de companhia, consequentemente, aumentando o risco para a saúde pública. A ausência da frequência da brucelose canina por B. abortus, em São João da Boa Vista, pode ser justificada uma vez que as amostras testadas terem sido encaminhadas pelo Centro de Controle de Zoonoses, sendo cães provenientes do centro urbano, que, podem não ter tido convivência direta com a pecuária da região.

Várias controvérsias existem quanto ao uso das provas sorológicas devido às diferenças na sensibilidade e especificidade destes testes ${ }^{8}$. Fatores como infecção precoce, fase abacterêmica e reações cruzadas com outros microorganismos Gramnegativos podem ter influenciado os resultados do teste IDGA para diagnóstico de brucelose canina por B. canis uma vez que se desconhecem informações do estado geral dos animais. Para evitar reações inespecíficas, deve-se, em uma próxima etapa, tratar as amostras positivas com 2 Mercaptoetanol $^{9}$, embora Melo et al. (1998), Maia et al. (1999) apud Aguiar et al. ${ }^{9}$ e Almeida et al. ${ }^{3}$ utilizaram em seus estudos apenas o IDGA como prova diagnóstica. Desta forma, conclui-se que mesmo com índices baixos de brucelose canina por $B$. canis e ausência por $B$. abortus, em cães errantes da cidade de São João da Boa Vista, há risco à saúde pública, uma vez que, por serem cães de rua o grau de transmissão desta doença é elevado. Além disso, novos testes devem ser conduzidos com as amostras positivas no intuito de eliminar reações inespecíficas, além de repetir as análises utilizando outras formas de diagnóstico laboratorial.

\title{
Research of antibodies anti-Brucella canis and anti-Brucella abortus in wanderring dogs in São João da Boa Vista, State of São Paulo, Brazil (2002-2003)
}

\begin{abstract}
Dogs brucellosis may cause reprodutive problems and there are a risk factors for human health. The prevalence of brucellosis due to Brucella canis and Brucella abortus was investigated in dogs living in urban areas of São João da Boa Vista/SP - Brasil. For this purpose, 500 blood sample were collected and serum analysed by agar gel immunodiffusion test and Rose-Bengal test. The frequency of brucellosis due to B. canis was 4/500 (0,8\%) and negative for B. abortus.
\end{abstract}

Key words: Brucellosis. Brucella canis. Brucella abortus. Serology. Dogs.

\section{Referências}

1 BERTHELOT, X.; GARIN-BASTUJI, B. A brucelose no cão. A Hora Veterinária, v. 16, n. 92, p. 47-50, 1996.

2 CARMICHAEL, L. E. Brucella canis. In: NIELSEN, K. H.; DUNCAN, J. R. Animal brucellosis. Boca Raton: Press, 1990. p. 336-350.

3 ALMEIDA, A.C. et al. Soroprevalência de brucelose canina na cidade de Alfenas, MG: dados preliminares. Arquivo Brasileiro de Medicina Veterinária e Zootecnia, v. 53, n. 3, p. 358-360, 2004.

4 MOLNÁR, E.; MOLNÁR, L.; CARVALHO, M. Capacidade de algumas provas sorológicas no diagnóstico de brucelose canina. A Hora Veterinária, v. 21, n. 121, p. $45-49,2001$

5 VALIN, M. E. R. et al. La brucelosis como enfermedad profesional: estudio de un brote de transmision aerea en un matadero. Revista Espanhola de Salud Publica, v. 
75, n. 2, 2001.

6 AZEVEDO, S. S. et al. Inquérito sorológico e fatores de risco para a brucelose por $B$. canis em cães do município de Santana de Paranaíba, Estado de São Paulo. Pesquisa Veterinária Brasileira, v. 23, n. 4, p. 156-160, 2003.

7 ALTON, G. G. et al. Techniques for the brucelosis laboratory. Paris: INRA, 1988. p. 190.

8 MOLNAR, L. et al. Concepções modernas para o diagnóstico da brucelose. Revista Brasileira de Medicina Veterinária, v. 19, n. 4, p. 157-162, 1997.

9 AGUIAR, D. M. et al. Ocorrência de anticorpos antiBrucella abortus e anti-Brucella canis em cães rurais e urbanos do Município de Monte Negro, Rondônia, Brasil. Ciência Rural, Santa Maria, v. 35, n. 5, p. 12161219, 2005 